\title{
Reflection
}

\section{Schooling During COVID-19 Pandemic: A High School Stu- dent's Perspective}

\author{
Kocjančič E ${ }^{1, *}$, Kocjančič B ${ }^{2}$
}

1. International School Gimnazija Bežigrad, Ljubljana, Slovenia

2. Department of Orthopaedic Surgery, University Medical Centre Ljubljana, Ljubljana, Slovenia

* Correspondence: ema.kocjancic@gmail.com

Citation: Kocjančič E, Kocjančič B. Schooling during COVID-19 pandemic: a high school student's perspective.Proceedings of Socratic Lectures. 2021; 6: 179-183. https://doi.org/10.55295/PSL.2021.D. 022

Publisher's Note: UL ZF stays neutral with regard to jurisdictional claims in published maps and institutional affiliations.

\section{Copyright: $(\mathcal{C} 2021$ by the authors.}

Submitted for possible open access publication under the terms and conditions of the Creative Commons Attribution (CC BY) license

(https://creativecommons.org/licenses/b $\mathrm{y} / 4.0 /)$.

\begin{abstract}
:
As the COVID-19 pandemic was declared on March 11th, 2020, numerous health restrictions were put into place to help slow down the spread of the infectious disease. One of those safety measures was online school which replaced the traditional in-school learning. While distance learning meant a safer and innovative alternative to traditional schooling during the pandemic, it severely impacted a number of students, especially those from a lower socioeconomic background. This is because those students very often did not have access to functioning electronic devices and stable network connections and therefore could not participate in online schooling. Additionally, learning from home greatly limited students' ability to socialise with their classmates, something that in-person schooling allowed for every day.
\end{abstract}

Keywords: On-line learning; Lockdown; Socialization; Digital platforms 


\section{COVID-19 and schooling}

\subsection{COVID-19 pandemic}

On January 31st, 2020, with the global death toll by COVID-19 (caused by SARS-CoV-2 virus; Severe Acute Respiratory Syndrome (SARS)) surpassing 200 and the quickly growing number of daily confirmed cases, the World Health Organisation (WHO) declared the infectious disease a public health emergency (AJMC, 2021). Throughout February, the number of confirmed infections exponentially grew, most visibly in China, where the infectious disease was first detected and described as unusual pneumonia at the end of 2019 (WHO, 2021). By February 10th, 2020, the number of deaths by COVID-19 in China surpassed the total number of deaths by the believed predecessor virus SARS-CoV-1 from 2004 (AJMC, 2021). Worldwide spread of the virus to 114 countries by air travel and cruising (AJMC, 2021) led to WHO declaring a pandemic on March 11th 2020, and encouraging world country leaders to do everything in their power to find a balance between protecting the public health, minimising socioeconomic consequences of health restrictions and respecting human rights (WHO, 2020).

Almost two years later, the number of all confirmed cases is nearing 277 million and the number of deaths 5.5 million (WHO, 2021). Several regulations that had been put into place at the beginning of the pandemic are still in use today, such as maintaining personal hygiene, wearing protective masks and, in some countries, online schooling.

\subsection{Lockdown of schools and online learning}

In a matter of weeks from the declaration of COVID-19 being a public health emergency, as many as 1.5 billion students worldwide were affected by the lockdowns that followed. Schools were opened and functioning as they normally had been one day, and the next day pupils found themselves learning from home in front of a computer screen with schools closed. The traditional face-to-face learning was replaced by online learning with the only means of communication between students and teachers being school-provided emails and digital platforms (OECD, 2021, p. 5), such as Zoom and Microsoft Teams. With their children staying at home all day, the proportion of adults working from home increased significantly and many workers, especially those with the youngest children, had to adjust their working hours to help their children take part in online learning and provide them support they needed for studying and doing homework (Thorn et al., 2021).

There was also a great difference between the accessibility of education to students of different social backgrounds. Rates of infections and COVID-19-related deaths were notably higher in areas with lower socioeconomic status which has put additional stress on students from such backgrounds or regions. In addition, many of those students also had difficulties with accessing network connections, as well as devices required for online learning, such as functioning computers and printers (OECD, 2021, p. 5). This was especially highlighted in lower income countries, such as sub-Saharan Africa where as many as $45 \%$ of students had no exposure to remote learning, and the rest were only exposed to such information via radio or TV (Saavedra, 2021). In Latin America, the situation was slightly better. For instance, in Mexico, about $60 \%$ students had access to remote lessons via television or radio (McMahan, 2021). In other middle-income countries, education accessibility differences were significant within the same country, with the elite minority receiving several hours of online lectures daily, while the rest settled for a few lessons via TV or radio. Such differences are also seen in the recent evaluations of the loss of expected learning with the poorest quintile losing over $20 \%$ more of the expected learning than the richest quintile (Saavedra, 2021). 
The sudden and unexpected transition to online learning or a combination of online and in-person learning not only put a strain on students, but also teachers who were mostly not familiar with online learning platforms but had to master them in a matter of days. Additionally, a lot of materials were not suited to online learning and classes, such as arts, language and physical education classes were seemingly impossible to conduct online (OECD, 2021, p. 5). Most countries provided teachers support during the transition between in-person learning and online learning in terms of training programs and courses on online teaching. Teaching content was also adapted with opening education resources and providing lesson plans (OECD, 2021, p. 34). Teachers' access to technology was one of the most frequently stated challenges among European teachers. The majority of countries resolved this by providing them ICT (Information and Communication Technologies) tools and network connectivity (OECD, 2021, p. 36).

\subsection{Outcomes and the future of learning}

To our best knowledge, extensive objective analyses of the effect of the COVID-19 on education have not yet been elaborated. However, subjective experiences and evaluations shared by countries and educational institutions have been performed. Publicly available online sources are consequently very mixed; on one hand, the transition from the well-established in-person learning to online hybrid learning was very rapid and thus allowed very little time for planning and training of personnel. Many teachers and students thus did not have access to technologies which would allow for them to participate in online schooling, or they did not know how to properly use the equipment that they had. In addition, technology is subjected to limitations - poor internet connections and non-working cameras and microphones. Most of all, some hands-on courses, such as physical education, dental hygiene etc. could not be taught online (University of Illinois Springfield, 2021). On the other hand, this new way of learning has introduced new, innovative models which also focus on integrating technology with education, modernising the school system ( $\mathrm{Li}$ et al., 2020). Some experts even claim that forms of hybrid online learning are the future of education. Many universities, such as Zhejian University, managed to move over 5000 courses completely online in a matter of two weeks (Zhaohui, 2020). Other experts (Li et al., 2020) even argue that a long-awaited new way of teaching which makes student-teacher interactions, document sharing and online research much faster and more efficient, has been discovered and will, even after the pandemic is over, become part of schooling.

\section{Reflection}

When schools in Slovenia abruptly closed in March 2020, I was in my second year of high school. When lockdown was announced, students and teachers were told that we would stay at home for the next two weeks as a precautionary measure against the spread of COVID-19. As the concept of online learning was almost completely foreign to us, it seemed to be an exciting new experience - we did not have to wake up as early as we usually would, and we could follow classes from the comfort of our homes. Back then, none of us thought that the pandemic was just starting, and that online schooling would actually become a long-term experience.

The primary form of communication with our teachers was school email that every student was assigned as they enrolled in high school. This form of communication was efficient, but sometimes, in the flood of emails received daily, information about online classes or homework or additional resources got lost. However, this was always resolved with communication among students, mostly over previously created social media class group chats.

At first, neither the students not the majority of teachers knew how online school would look like. This gave most teachers the freedom to come up with their own system 
that we were introduced to during the first week of online classes. Generally, we had one online lesson weekly per subject and in between those lessons we studied textbooks and completed worksheet by ourselves. After the first two weeks of lockdown quickly passed and there was no talk of returning to school in-person, we soon realised that online learning had become a new reality and we had no choice but to get used to it. I believe it was this realisation that encouraged us students, as well as teachers, to do our best communicating and helping each other - after all, we were all in this together. After about one month, everyone was used to online schooling and had their own rhythm and system of working. Until the end of the school year we were graded at least once per subject, most often by written examinations during which we had to turn on our cameras and place them so that our workspace was seen. Meanwhile, classes then continued in a similar manner as before, that is, one or two online lessons per subject per week in addition to textbooks and worksheet.

We started the next school year, my third year of high school, in person. As I had just joined the two-year International Baccalaureate Diploma programme at my school, I started the year in a new classroom filled with students who did not know each other, so the seven weeks we spent physically in school were very valuable to us, as we were just getting to know each other. Since the beginning of the year, we were all prepared for the possibility of online school, so we mostly got instructions as to how online classes would look like for each subject in advance. When the state of the pandemic did indeed get worse a few weeks after the school year began, we once again switched to online schooling. Having spent prolonged periods of time at home the previous year too, it felt as if the time spent in schooling online was the time when socialisation was put on pause. This was mostly due to the lack of breaks in-between lessons that we would otherwise spend in a classroom together. At home the breaks were spent with the computer camera turned off. So, for the duration of online schooling which lasted for about five months, my classmates and I spent little to no time getting to know each other and mostly stayed in contact with our other acquaintances and friends. This lack of connection between us is still seen today; while we are classmates who see each other every day, we have not formed many meaningful friendships among each other.

During the second lockdown, schooling was a bit different and more organised; all classes that we would have at school in person were held online, following the same schedule. This made keeping track of assignments and online lectures much easier than during the first year, however, it was also much more time consuming, and I had often found myself finishing classes at $5 \mathrm{pm}$ when it was already dark outside. This combined with the fact that my bedroom had essentially become my classroom and the room I wrote my exams in, both contributed to my overall lack of motivation to do school-related work after class, and my increased need to go outside multiple times per day to get away from the computer screen. I often had headaches and strained eyes following the entire day of online lectures attended with a computer screen.

To sum up, online schooling was a very interesting experience which allowed for the safest way of learning during the pandemic. However, the lack of socialisation and changing of my everyday environment is what had me hoping every day that things would finally return back to the old normal, and that I would again be able to attend school in-person again.

Conflicts of Interest: The authors declare no conflict of interest.

\section{References}

1. AJMC Staff (2021), A Timeline of COVID-19 Developments in 2020. Updated 2021. Accessed 26.12.2021. Available from https://www.ajmc.com/view/a-timeline-of-covid19-developments-in-2020

2. University of Illinois Springfield (2021), Strengths and Weaknesses of Online Learning. Accessed 28.12.2021. Available from https://www.uis.edu/ion/resources/tutorials/online-education-overview/strengths-and-weaknesses/ 
3. Li C, Lalani F (2020). The COVID-19 pandemic has changed education forever. This is how. Accessed 28.12.2021. Available from https://www.weforum.org/agenda/2020/04/coronavirus-education-global-covid19-online-digital-learning/

4. McMahan B (2021), Education in Latin America after the pandemic. Accessed 29.12.2021. Available from https://news.mit.edu/2021/education-latin-america-after-pandemic-1029

5. OECD, The state of school education: One year into the COVID pandemic. 2021; pp. 5-36. Updated April 2021. Accessed 27.12.2021. Available from https://read.oecd-ilibrary.org/education/the-state-of-school-education_201dde84-en\#page1

6. Saavedra J (2021), A silent and unequal education crisis. And the seeds for its solution. Accessed 28.12.2021. Available from https://blogs.worldbank.org/education/silent-and-unequal-education-crisis-and-seeds-its-solution

7. Thorn W, Vincent-Lancrin S. Executive Summary. In: Schooling During a Pandemic: The Experience and Outcomes of Schoolchildren During the First Round of COVID-19 Lockdowns. OECD Publishing 2021. https://doi.org/10.1787/d106fff3-en.

8. WHO (2020), WHO Director-General's opening remarks at the media briefing on COVID-19-11 March 2020. Accessed 27.12.2021. Available from

https://www.who.int/director-general/speeches/detail/who-director-general-s-opening-remarks-at-the-media-briefing-on-co vid-19---11-march-2020

9. WHO (2021), WHO Coronavirus (COVID-19) Dashboard. Accessed 26.12.2021. Available from https://covid19.who.int

10. WHO Team (2021), WHO-convened global study of origins of SARS-CoV-2: China Part. Accessed 26.12.2021. Available from https://www.who.int/publications/i/item/who-convened-global-study-of-origins-of-sars-cov-2-china-part

11. Zhaohui $\mathrm{W}$ (2020), How a top Chinese university is responding to coronavirus. Accessed 28.12.2021. Available from https://www.weforum.org/agenda/2020/03/coronavirus-china-the-challenges-of-online-learning-for-universities/ 